HAJDÚ ZOLTÁN:

\title{
VONZÁSKÖRZETKUTATÁS A FELSZABADULÁS ELÖTTI MAGYAR FÖLDRAJZTUDOMÁNYBAN
}

$A z$ I. világháború elötti magyar földrajztudomány nemzetközileg elismert vonulata a természeti földrajz. Meghatározó az analitikus jellegü természettudományi irányzat, mely kevés figyelmet fordít a társadalmi, településhálózati jelenségek kutatására. Az emberföldrajzi (társadalomföldrajzi) kutatások nehezen, vontatottan indultak, elméleti alapvetésük ellentmondásosan alakult, az alapkategóriák tartaima nehezen formálódott, fejlödésük bizonytalan eiméleti bázison ment végbe.

A háború utáni változások nyomán felértékelödtek a társadalomföldrajzi kutatások eredményei. A magyar földrajztudomány az új helyzetben a korábbiaknál erö. teljesebben fordul a gazdaság, a népesség, a településhálózat kutatása felé.

Minden tudomány alapvető érdeke és feladata az alapkategóriák tartalmának folyamatos elemzése. Az alapkategóriák történeti fejlőd ésének megismerése hozzájárui a mai folyamatok értelmezéséhez is.

A tanulmány a felszabadulás elötti társadalomföldrajz egyik kategóriájának részletes, adatszerü feltárását, elmélettörténeti kérdéseinek elemzését, értelmezését tüzi ki célul. Áttekinti a vonzáskörzet fogaimának kialakulását, fejlödését, elméleti alapjainak változását, a kutatások módszertani apparátusának kiszélesedését, s utal a kutatások nemzetközi kapcsolódásaira.

\section{A vonzáskörzeti problematika felvetódése}

és a vonzáskörzetkutatások irányzatai

A vonzás (gravitáció) általános érvényủ fogalom a XX. sz. eleji magyar földrajztudományban. A legáltalánosabb használati köre a településföldrajzban alakult ki. $A z$ elönyös földrajzi feltételek vonzzák a települést (települést vonz a folyó, a forrás, a hegylábi felszín; a nagyobb városok vonzzák az utakat, a falvak népességét, a nyersanyag a feldolgozóipart stb.).

A vonzás meliett hasznáit fogalmak a centrum, a központ, a tájközpont, a táj vonzáscentrum kifejezések is. (Ezeket a fogalmakat a hagyományos történeti-néprajzi indíttatású településföldrajz már a XiX. sz. végén is használta.) PRINZ GY. még a típusképzés során is kitüntetett szerepet tulajdonitott a vonzás jelentőségének. Vonzásos 
útifalu úgy jön létre, hogy a házak az út vonzó hatására fokozatosan kitelepednek az út széléhez. ${ }^{1}$

A továbbiakban személyenként, illetve irányzatonként tekintem át a magyar településföldrajzban a vonzáskörzeti problematika fejlödését. Nem térek ki minden kutató, illetve kutatás elemzésére, csak azokat emelem ki, akik valamilyen területen jelentős elörelépést hoztak.

\section{PRINZ GYULA vonzáskörzet-felfogása}

A vonzáskörzet, a vonzásterület fogalmának kialakulása a magyar földrajzi irodalomban egybekapcsolódik a PRINZ által meghonosított, a "legegzaktabb emberföldrajzi tudományág", a közlekedésföldrajz fejlődésével. Eredete a német közlekedésföldrajz „Hinterland” fogalmára vezethető vissza. Értelmezése kezdetben leszükül a kikötők területi kapcsolatainak jellemzésére: "Háti-ország alatt a kikötő közvetlen vonzási területét értjük, amelyet még teljesen uralni tud más kikötők versenye nélkül."2 A „közvetlen vonzási terület” fogalmat megkülönbözteti attól a területtől, amely még szállít az illető kikötőbe, de már más kikötőkkel is kapcsolatban áll.

Ettől kezdve PRINZ felváltva használja a Hinterland és a vonzási terület kifejezéseket közlekedésföldrajzi munkáiban. A két kifejezés használat köre, tartalma fokozatosan bövül, egyre inkább elszakad a kikötók speciális vonzási területének fogalmi körétöl és általános közlekedésföldrajzi, majd településhálózati kategóriává válik nála.

PRINZ vonzáskörzeti felfogása figyelemre méltó a közigazgatási területszervezés szempontjából is. 1923-ban a regionális közigazgatási beosztás számára kidolgozott közlekedésföldrajzi fövidékeket olyan területnek tekinti, amelyek „...egyúttal váro. saik vonzásterületét is jelentik."3 A vonzásterület fogalma itt még döntően közlekedésföldrajzi, de már gazdasági, közigazgatási, kulturális elemeket is magába foglal. A közlekedésföldrajzi elérhetöség alapján határozza meg az ország városainak vonzásterületét, s ezekre a vonzásterületekre kívánja felépiteni a közigazgatási beosztást.

1925-ben részletes, empirikus vonzáskörzetvizsgálatokat végez. Ütközteti Pécs "természetes vonzásterületét" és a vasúti izokron térképek által biztositott lehetőségeket, kitér a vonzásterület, a közigazgatási területszervezés, a közlekedési és gazdasági kapcsolatok kölcsönhatására. ${ }^{4}$ Feltárja, hogy Pécs természetes vonzásterületét a közle. kedési hálózat igen hiányosan kapcsolja a városhoz.

A vonzásterület, mint kategória strukturálódik. Pécs vonzásterületét két övezetre osztja: 1. szomszédság-övezet, 2. vonzásövezet. Szomszédság-övezetnek tekinti azt a területet, amelyről reggel 6 órától este 10 óráig terjedő időszakban úgy lehet megjárni a várost, hogy legalább 10 óra hasznos idót lehet benne el tölteni. Vizsgálatai alapján a szomszédság-övezet Pécs esetében a budapesti vasútvonalon Abaligetig, a mohácsin pedig Magyarbólyig húzódik. Vonzásövezetnek azt a területet tekinti, amelyrōl reggel 6-kor indulva és este 10-re visszaérkezve a város felkereshető úgy, hogy legalább 2 hasznos órát lehetne benne eltölteni.

PRINZ véleménye szerint a közlekedésföldrajzi alapon meghatározott és belső szerkezetében differenciált vonzásterület fogalom elvileg minden város esetében értel. mezhető, az egyes városok szomszédság- és vonzásövezetei átfedik egymást, s a városok harcot folytatnak ezen területek kiszolgálásáért. 
1933-ban ismét továbblép a vonzáskörzet-kutatás elméleti és szemléleti alapjait és gyakorlati felhasználhatóságát illetően is. ${ }^{5} \mathrm{Az}$ ország piaci, vásári kereskedelmi központjainak feltárása, a kereskedelmi vonzás- és kapcsolatrendszer értelmezése után a vonzáskörzeti kapcsolatokat kivetíti a közigazgatási területszervezés járási szintjêre is: „Elméletben minden vásárhely szoros vonzási területe egy államföldrajzi sejtcsaládot alkot."6 A területszervezés további szintjein (megye, kerület) is kitüntetett szerepet tulajdonít a vonzásterületeknek.

A megye és a városhálózat kapcsolatait elemezve feltárja, hogy „....minden városnak kialakul gazdasági vonzásterülete, a helyzet csakhamar az volt, hogy a politikai vármegyétöl függetlenül keletkezett városok egy-egy gazdasági megyét alakítottak ki, a kettő területe, valamint útvonalhálózataik nem estek egybe."7

PRINZ tehát az 1930-as évek elején eljut a vonzásterületek és a közigazgatási egységek egybekapcsolásának gondolatáig, söt szükségszerüségéig.

Az 1930-as évek második felében megjelenö Magyar Földrajz 3 kötetében öszszegzi vonzáskörzeti kutatásait és szemléletét. ${ }^{8}$ Egyrészt - elsösorban TELEKI hatására - bővül a vonzáskörzeti kutatásai történeti, gazdasági, társadalmi összetevőinek köre.

A XVIII. századtól hosszú távú fejlődés eredményeként értelmezi a magyar városhálózat fejłődését, átalakulását. $A$ XVIII. sz. városai még jelentós mértékben önellátóak, de fokozatosan kifejlódnek az egész ország területén azok a városok, „...melyek elég tág vonzáskörzetüknek fogyasztó piacai lettek."9 Ezek a városok hatással vannak szükebb és tágabb környezetükre, strukturálják a mezőgazdasági termelést. (Tehát PRINZ nem egyszerü, formális viszonynak tekinti a vonzásterületi kapcsolatokat, hanem a város hatása alatt élő, átalakuló, a város igényeihez alkalmazkodó szerves egésznek.)

Különösen Budapest körül szemléletes ez a jelenség. „Budapest természetes vonzásterülete az egész ország" ${ }^{10}$, s ezen belül mintegy $70 \mathrm{~km}$-es kertgazdasági köre van, ezt a belterjes földmüvelés foltjai által alkotott gyürü veszi körül, a kü/terjes földmüvelés és az erdögazdálkodás gyúrüje is felismerhető. A külső körök Ny-on nem zárulnak be, ebben jut kifejezésre a nyugat-európai nagy piac vonzóerejének hatása. (A vonzásterület itt gazdasági makrokategóriaként szerepel, országhatárokon belül is strukturálódik, s e mellett egyértelmúen hat a nemzetközi munkamegosztás is.)

A kapitalista fejlödés új módon veti fel a településhálózat, a vonzásterületek kérdését is. $A$ XIX. sz. végétől átalakulnak a zárt, városközeli körzetek. "Megszünt a városok vidéke a város saját kizárólagos vonzásterülete lenni, és igy annak termelése, gazdasági fejlettsége a város méretét meghatározó lenni. A városok szabad versenyben terjesztették szét vonzásterületeiket közelebbi és távolabbi szomszédjaik rovására, sőt átugorva azokat, egészen távoli területekre is."11

A vonzásterületet e/sösorban nagyvárosok körüli, átfogó kategóriaként fogalmazza meg. Részletesen foglalkozik a kialakuló vonzásterületek belső struktúrájával is. Általános érvénnyel állapítja meg: „A nagyvárosnak vonzásterületét a földrajzban az összefolyó átmenetek ellenére is két gyürüre bonthatjuk szét. $A$ belső gyürü a teljes vonzás területe, amelyen idegen nagyváros hatása csak a saját nagyvárosán keresztül, tehát ennek közvetítésével érvényesül, vagy egyébként igen halványan. A külső gyürü két nagyváros közös hatásterülete."12 
Részletesen elemzi Budapest vonzásterületének „földrajzi gyürüi"-t. Bécs-Budapest vonatkozásában kifejti, hogy a Monarchia időszakában Bécs vonzási hatása kiterjedt az ország Ny-i részeire, melyek közvetlenül Bécs vonzáskörzetébe tartoztak. PRINZ szerint Budapest belsö gyürüje a Vág-völgyön, Györön át a Bakonyig, a pozsegai Papukig húzódik. Budapest szellemi vonzása a Balkánon is messzire ható, de az AlDunán túl elhalványuló.

PRINZ jelentós munkát végzett az ágazati vonzáskörzetek kutatásában is. Különösen fontos a kereskedelmi vonzáskörzetek ${ }^{13}$ és az idegenforgalom vonzáskörze. ti hatásának vizsgálata. ${ }^{14}$

PRINZ vonzáskörzeti kutatásai közlekedésföldrajzi vizsgálataiból nöttek ki. Felfogását elsősorban a német közelekedés- ès településföldrajz befoiyásolta, de kisebio mértékben megjelenik a francia emberföldrajz szemléletformáló hatása is.

\section{TELEKI PÁL és a vonzáskörzetek}

A felszabadulás utáni magyar vonzáskörzet-kutatások egyik komoly akadálya sokáig az volt, hogy az első nagyarányú, szervezett vonzásvizsgálatok szorosan kapcsolódtak a trianoni békeszerzödésre való tudományos előkészületekhez, a Béketárgyalást Elökészitő Iroda tevékenységéhez. ${ }^{15}$

TELEKI 1918 ószétól a magyar geográfusok egy részét bevonta a békeelökészitő munkákba. Biztositotta számukra a legfontosabb személyi, anyagi, tárgyi feltételeket, statisztikai anyagot. ${ }^{16} \mathrm{E}$ vizsgálatok felölelték a gazdaság, a népesség, a települések funkcióinak, különbözö jellegü szféráinak feltárását. A kutatási eredmények elsősorban tervezett államhatár kritikáját szolgálták. (KOVÁCS A. elkészítette a "Magyar városok vonzásterületei" c. térképsorozatát, de a sorozatból csak Budapest és az ún. elszakadásra ítélt városok - Pozsony, Temesvár, Kassa, Nagyvárad, Arad, Kolozsvár -vonzáskörzeti térképei jelentek meg.) ${ }^{17}$

Magyarország első gazdaságföldrajzi szintézise TELEKI tanszékén született. Adatbázisát főleg a békeelökészítés kapcsán gyújtötte össze FODOR FERENC. ${ }^{18}$

FODOR is a közlekedési vonzásterületek vizsgálatát helyezi elötérbe. Vizsgál . ja és értékeli Budapest, Fiume vonzásterületét, de sajátos módon elemzi egyes vasút. vonalak és egyes tengerek vonzásterületét is.

A városok vonatkozásában FODOR egyfajta központi hely elméletet képvi.. sel. Egybekapcsolja a városnagyság és a vonzásterület problémáját: „... városaink nagy. sága és gazdasági forgalma arányos a mögöttük fekvő vonzási terület kiterjedésével és gazdasági erejével." 19

FODOR árnya!tan közelíti meg a vonzás, a vonzásterület fogalmát; közlekedési, természeti, természetes, politikai, gazdasági, kereskedelmi, kulturális vonzásról, ill. vonzásterületröl beszél.

A város-vidék kölcsönhatásban a gazdasági életnek, a gazdasági kapcsolatoknak tulajdonít nagy jelentőséget. Budapest elemzése kapcsán bebizonyítja, hogy a város nagy gazdasági energiái nem maradnak meg a közigazgatási határokon belül, hanem egész városi körzetet hivnak életre. E városi körzet 3 fö övezetre bontható: 1. a közigazgatási Budapest; 2. a külvárosok övezete(ipari övezet); 3. a szomszédos övezet (intenzív mezögazdasági öv). 
$A z$ övezeti rendszernek megfelelően alakul a népesség foglalkozási szerkezete is. Az első öv föleg a kultúrtermelö lakosságot, a második az ipari munkásságot, a harmadik a parasztságot tömöríti.

TELEKI átfogó, tudományos igénnyel - elszakadva már a békeelőkészités napi politikai, határkritikai felhasználásától - föleg a várossal foglalkozva érintette a vonzáskörzetiség problémakörét. ${ }^{20}$ Egyetemes jelleggel, elmélyült történeti, természetés gazdaságföldrajzi, kultúrtörténeti, közigazgatási és statisztikai ismeretek birtokában, szociológiai kitekintésel foglalkozott a város fogalmi, kialakulási, fejlődési, funkcionális kérdéseivel.

Kiinduló pontja, hogy a város minden korban, a Földnek minden részén, minden államban viszonylagos fogalom, amely a többi településtöl lényeges jegyek alapján különbözik. A többi településtöl mindenkor nagyobb, ezeknek gazdasági vagy politikai vonatkozásban, gyakran mindkettőben, valamiképpen központja. A városok a politikai hatalom várai, a vallás templomai, a társadalmi vonzás fórumai és a gazdasági anyagcsere vásárterei közül alakultak ki. A város maga is egy funkciója a társadalmasodásnak.

A város élete során erőteljesen hat környezetére, nem zárkózik be falai közé. A fejlődő, növekvő város önmaga körül a városiasodás belső és a vonzásterület külsö köreit nagyobbitja. A vonzásterületeknek többféle típusa különíthető el. Speciális vonzásterület a Hinterland, amelyet a kikötők vonzásterületére szükít le, de szélesebb értelemben is használja. Elemzi a politikai, gazdasági, társadalmi, müvelődési kapcsolatokat, s megállapítja, hogy különösen nehéz a városok kulturális vonzás-, illetve hatásterületének meghatározása, mivel ezek a kapcsolatok egészen eltérő nagyságú területekre terjednek ki.

A politikai hatás- és vonzásterület sok esetben (pl. egyes extenziv államok fövárosa, illetve a nagy gazdasági központok vonzásterülete) túllépi az államhatárokat is. A vonzásterület fogalmát így térben erősen differenciált nagyságrendi kategóriaként kezeli.

A város-vidék kapcsolat kölcsönhatásának kutatásakor TELEKI több helyen fogalmi különbséget tesz a város vonzásai, hatásai és befolyása között. A legszélesebb kategória a befolyásterület. Ez magában foglal minden hatást. A város vonzásterülete az a térség, amelyet a város különféle szolgáltatási jellegủ kapcsolatai útján vonz. Ellátó terület a vidéknek az a része, ahonnan a várost élelmiszerrel rendszeresen ellátják.

1936-ban világméretekben vizsgálja a városiasodás természeti, gazdasági, társa-

dalmi, települési, politikai folyamatait, illetve következményeit. ${ }^{21}$ Itt a legsokoldalübb a város körül kialakuló térstruktúrák elemzése, a város-vidék közötti kapcsolatok értelmezése.

THÜNEN elméleti megállapításait továbbfejlesztve európai és világméretekben vizsgálja a mezőgazdaság intenzitásának fejlődését, $s$ allapitja meg a nagy piacok körül kialakuló ellátó területek térbeli rendjét, s úgy látja, hogy az átstrukturálódás a központból indul, annak hatása, befolyása alatt megy végbe.

TELEKI irodalmi ismeretei, forrásai és hivatkozásai igen széles körben mozognak. Felfogására hatott a német, a francia és az angol földrajzi, történeti, szociológiai, közigazgatási, közgazdasági irodalom, s kísérletet tett arra, hogy ezeket a hatásokat egyéni szintézisbe ötvözze. 


\section{MENDÖL TIBOR és a debreceni vonzáskörzetkutatások}

Kezdetben MENDÖL nem vezetője, nem irányitója a Debrecenben folyó településföldrajzi kutatásoknak, de munkásságával meghatározza ezek jelentőségét. $A$ debreceni vonzáskörzetkutatásokat elsósorban az alföldiség, az alföldi városok vizsgálata köti össze.

MENDÖL az 1930-as évek elejétől szentel nagyobb figyelmet a településköz:i kapcsolatok problematikájának, bár már a Szarvas földrajza c. munkájában ${ }^{22}$ is használja a gazdasági jelenségek leírásakor a vonzás, a gazdasági vonzás fogalmát, de még nem értelmezi átfogó módon a központ és vidéke közötti kapcsolatokat.

1931-ben közlekedésföldrajzi elemzésekkel kezdi meg Debrecen vonzásterületének kutatását. ${ }^{23}$ A vonzásterület e/sódlegesen közlekedésföldrajzi meghatározottságú, de világosan megfogalmazza azt is, hogy a közlekedésföldrajzi helyzet és az izokronok nem határozzák meg önmagukban a város vonzásterületét. A vonzásterület kiterjedésében a történetileg kialakult településközi kapcsolatok is jelentős szerepet játszanak. Az izokron térképek a pillanatnyi állapot meghatározásához nyújthatnak elsősor. ban segítséget. A vonzásterület szerves egység, amellyel a város szorosabb gazdasági kapcsolatban áll, ahonnan a saját fogyasztására vagy ipari üzemeinek ellátására szüksé. ges nyersanyag nagy részét beszerzi, ahol iparcikkeinek javát értékesíti, amely számára kis- vagy nagykereskedelme közvetíti saját vagy idegen tájak terményeit, ahonnan népessége bevándorlókkal gyarapszik. Összegezve: a táj számára ez a város jelenti gazda. sági és szellemi tekintetben is a "város"-t. Megjelenik elemzésében a város - illetve von. záskörzet-hierarchia problémája is. Debrecen vonzásterületén belül vizsgálja Nyíregyháza és Békéscsaba másodrendü vonzásközpontok izokronjait is. Felveti Debrecen von. zás-szférájának zónaszerủ jellegét, de nem tér ki részletes elemzésére.

Legátfogóbban a helyzeti energiák és a városok valódi nagyságának meghatározásakor foglalkozik a vonzásterületek, a városhálózat funkcionális és hierarchikus problémáival. ${ }^{24}$ MENDÖL empirikus vizsgálatokból kiindulva szinte önállóan fogalmazza meg a központi hely elméletét. CHRISTALLER-től eltérően nem a modellszerúséget helyezi elötérbe, hanem nagyon erös tájföldrajzi szemléleti megközelítésben vizsgálja és tárja fel a táj - település - központ fogalmak közötti kapcsolatokat. ${ }^{25} \mathrm{MEN}$ DÖL nem vonatkoztat el teljesen attól, hogy a jelenségek konkrét földrajzi térben játszódnak le. Nem formalizált rendszert dolgoz ki, inkább a konkrét, empirikus elemzés, a közvetlen megfigyelés eredményeinek értékelése után dolgozza ki központi hely elméletét.

Szemlélete emellett erősen történeti megalapozottságủ is. A történetileg kialakult mezővárosi, zárt vonzásterületek feltárása után elemzi a vasútépítések hatását, s mutat rá, hogyan törte szét ez a folyamat a mezővárosok autark vonzásterületeit. Elemzi a települések hierarchikus rendje és a vonzáskörzetek közötti kapcsolatokat. Kimutatja, hogy a településhálózat hierarchikus tagolódása következtében a vonzásterületek is hierarchikus rendet alkotnak. Budapest a legmagasabb szintü központ, vonzáskörzete sok tekintetben az egész ország. Debrecen másodrendü központ. Debrecen vonzáskörzetén belül Nyíregyháza harmadrendü központ, s ezen belül Kisvárda negyedrangú vonzásterületet alakit ki.

MENDÖL világosan látja, hogy a vonzásterület nem statikus, hanem dinami: 
kusan változó egység. A vonzásterületek kezdetben zárt, elszigetelt egységként jöttek létre, majd a gazdasági fejlödés, a munkamegosztás elmélyülése révén fokozatosan tel. jes térkitöltésü rendszerré válnak, végül pedig kialakul egymást kölcsönösen befolyásoló, átfedő, kusza területi struktúrájuk.

MENDÖL hierarchikus rendszere erösen kötődik a közigazgatás tagolódásához is. Ez arra enged következtetni, hogy a közlekedési kapcsolatok mellett lényeges szerepet tulajdonít a vonzáskörzetek formálódásában a közigazgatás befolyásoló tevékenységének is.

1944-ben MENDÖL hallgatóinak segítségével Magyarország egész területén kipróbálta CHRISTALLER módszerét. ${ }^{26}$ Megállapította, hogy a módszer alkalmazása pozitiv és negativ eredményeket egyaránt eredményezett.

Munkássága mellett MÁRTON BÉLA tevékenysége emelhető ki a debreceni vonzáskörzetvizsgálatokból. MÁRTON összefoglalja az addigi közlekedésföldrajzi vonzáskörzet-kutatások eredményeit, s kisérletet tesz néhány város közlekedésföldrajzi vonzásterületének meghatározására. ${ }^{27}$ Elméletileg a legszélesebben veti fel a városok "élettér"-kérdéseit, s ezzel a felszabadulás előtti földrajzi irodalomban a legközelebb jut a komplex vonzáskörzet fogalmának meghatározásához.

\section{CHRISTALLER hatása KOGUTOWICZ KÁROLY vonzáskörzetkutatásaira}

KOGUTOWICZ sajátos történeti, természeti, társadalmi, gazdasági, településhálózati tájfogalmat dolgozott ki, ill. képviselt. A Dunántúl és Kisalföld írásban és képben c. munkájában ${ }^{28}$ kisérletet tesz e felfogás érvényesitésére.

A vonzáskörzet-kutatások szempontjából a legfontosabb, hogy Magyarországon KOGUTOWICZ K. alkalmazta először tudatosan CHRISTALLER módszerét a településhálózat hierarchikus rendjének feltárására. (A módszert eléggé leegyszerūsitett módon alkalmazta.) A Dunántúl összes városára vonatkozóan vizsgálta a telefonállomások számát és megoszlását, s ennek eredményeként elemezte röviden a nagyváros, a kisváros és a vidék közötti különbségeket. ${ }^{29}$

Tanitványai között egyszerre hat és érvényesül a tájföldrajzi és funkcionális szemlélet hatása a vonzásvizsgálatokban. ${ }^{30}$ BÁNKUTI F. CHRISTALLER módszerével vizsgálta Sátoraljaújhely központosultságát, s így bizonyította, hogy Sátoraljaújhely a legmagasabb hierarchikus szinten álló hegyaljai város.

\section{III. Összegzés}

Röviden áttekintve a felszabadulás elôtti magyar vonzáskörzet-kutatások problematikáját, megállapithatjuk, hogy e vizsgálatok - leszámítva az 1918-1920 közötti országhatárkritikához kapcsolódó elemzéseket - nem öltenek átfogó jelleget, bár a magyar földrajztudomány majd minden jelentős képviselője érintette valamilyen módon a településközi kapcsolatok problematikáját.

Nagyon elnagyoltan, kidolgozatlanul, a vonzáskörzeti probléma minden 
lényeges elméleti, szemléleti kérdése felvetödött valamilyen módon, sőt megkezdödött a vonzáskörzetek gyakorlati, tervezési felhasználhatósága kérdéseinek vitája is.

A PRINZ, TELEKI, KOGUTOWICZ tanitványaitól származó egyetemi doktori disszertációk az egyes településekre kiterjedöen is felvetik a vonzáskörzetképzödés kérdéseit, de MENDÖL tevékenységében van a legnagyobb jelentősége az elméleti és empirikus kutatásoknak.

A kutatások során a fogalmi megközelítés folyamatosan gazdagodik, de nem alakult ki a vonzáskörzet-kutatás egységes fogalmi apparátusa. $A$ város, a vonzáskörzet: fogalmának kérdése széles körben vetödik fel, de csak TELEKI és MENDÖL tesz kísér. lețet a felvetődő kérdések általánosabb feltárására, rendszerezésére.

A magyar vonzáskörzet-kutatásokra elsősorban a német településföldrajz szemlélete hatott, tiszta formájában elöször KOGUTOWICZ tesz kísérletet a CHRIS. TALLER-módszer alkalmazására, majd MENDÖL a továbbfejlesztés és az ellenőrzés kérdéseivel is foglalkozik.

A módszertani szemlélet fejlödése különösen a közlekedésföldrajzi vonzásvizs. gálatokban következett be. $A$ többi területen nem alakult ki sajátos vizsgálati mód. szertan.

\section{JEGYZETEK}

1. PRINZ GY. 1922: Magyarország településformái. Bp. pp. 7-8.

2. PRINZ GY. 1905: Fiume és kikötő-versenytársainak a földrajzi helyzet nyújtotta elönyök. Vasúti és Hajózási Hetilap. 7. évf. p. 336

3. PRINZ GY. 1923: Földrajz az államigazgatás szolgálatában. (Szerk.: TELEKI P.-BEZDEK J.KARL J.) Zsebatlasz 1923. Bp. pp. 154-157.

4. PRINZ GY. 1925: A Pécs-környéki vasúthálózat közlekedésföldrajzi kritikája. Pécsi Napló, 149. sz. dec. 10. p. 1.

5. PRINZ GY. 1933: Földrajz az államigazgatás szolgálatában. Földr. Közlemények LXI. 4-6.

6. Uo. p. 73.

7. PRINZ GY. 1933: Új megyerendszer. Magyar Szemle, XVIII. 2 (70) sz. p. 111.

8. PRINZ GY.-TELEKI P.-CHOLNOKY J. é.n.: Magyar Földrajz I-III. Bp.

9. Magyar Földrajz II. köt. p. 184.

10. Uo.

11. Uo. p. 413.

12. Uo. III. köt. p. 19.

13. PRINZ GY. 1934: Magyar vásárhelyek. Földrajzi Közlemények LXII. pp. 51-63.

14. A vendégforgalom vonzóhelyei. Magyar Földrajz III. köt. pp. 121-137.

15. CHOLNOKY J. (szerk.) 1920: A magyar béketárgyalások I-IV. köt. M. Kir. Külügyminisztérium. Bp.

16. FODOR F. 1919: A békeelókészítés földrajzi vonatkozású munkálatai. Földrajzi Közlemények XLVII. 1-10.sz. pp. 45-47.

17. BÁTKY ZS.-KOGUTOWICZ K. 1922: Kogutowicz Zsebatlasza 1922. Bp. pp. 167-168. 39 térkép. Magyar városok vonzásterületei.

18. FODOR F. 1924: Magyarország gazdasági földrajza. Bp.

19. Uo. pp. 218-219.

20. TELEKI P. é.n.: Város. Közgazdasági Enciklopédia. IV. köt. Bp. 1351-1378.

21. TELEKI P. 1936: A gazdasági élet földrajzi alapjai. I-II. köt. Bp. Különösen 590-652 pp. 
22. MENDÖL T. 1981: Szarvas földrajza. Békéscsaba. Hasonmás kiadás.

23. MENDÖL T. 1931: Debrecen közlekedésföldrajzi helyzete és az izokron térkép. Debreceni Szemle, 5. pp. 81-85.

24. MENDÖL T. 1935: Városaink valódi nagysága és a helyzeti energiák típusai. Földrajzi Közlemények LXIII. pp. 361-366.

MENDÖL T. 1936: A helyzeti energiák egyéb tényezók szerepe városaink valódi nagyságá. ban és jellegében. Földrajzi Közlemények LXIV.pp. 98-108, 121-132.

25. MENDÖL T. 1932: Táj és ember. (Az emberföldrajz áttekintése.) Bp.

26. MENDÖL T. 1963: Általános településföldrajz. Akadémiai Kiadó, Bp. p. 486.

27. MÁRTON B. 1939: Vasúttávolság és vásárhelytávolság a Nyírségben. Debreceni Szemle, pp. $323-335$.

MÁRTON B. 1942: Néhány városunk vasutainak vonzásterülete. Földr. Közl. LXX. pp. 135150.

28. KOGUTOWICZ K. 1930-1936: Dunántúl és Kisalföld irásban és képben. I-II. köt. Szeged. 29. Uo. II. köt. pp. 318-319.

30. KOVÁCS E. 1939: Pápa. (Szerk. WAGNER R. Kogutowicz Károly emlékkönyv.) Szeged, pp. 99-195.

BÁNKUTI E. 1941 : Sátoraljaújhely földrajza, Szeged. 